J. Product. \& Dev., 15(1): 27 - 36 (2010)

\title{
GENERAL STRUCTURE AND INNERVATION OF SPINDLE MUSCLE OF THE DABB LIZARD, Uromastix acanthinura
}

\section{A. El-Tarhonui and S.Saleh}

Department of Zoology, Faculty of Science, Garyounis University, Libya.

\section{ABSTRACT,}

The structure and innervation of spindle muscle in Uromastix acanthinura was studied. The skeletal muscles were stained with silver impregnation, dissociated and mounted in glycerin. The spindles were completely isolated from the extrafusal muscle fibers. It was found that in the lizard the spindles had only a single intrafusal fiber, they were of two types:

1-A long capsule with a long indistinct closely fitted capsule surrounding the muscle fiber and afferent nerve endings.

2-A short capsule spindle with a broad prominent capsule that extended for a short distance along the intrafusal muscle fiber.

In long spindles the sensory ending entered the capsule and branched at the point of entrance and then ran for a distance on the top of intrafusal fiber.

In short spindles, the sensory ending entered the capsule and then branched into a number of fine filaments each came in contact with the intrafusal fiber.

3-A complex spindles were observed and they were having two forms:

a-Paired linkage where spindles lay side by side.

$b$-Tandem spindle which contained two adjacent sensory regions.

4-The extrafusal muscle fibers were of two types:

a-A granular extrafusal muscle fibers which were innervated by motor nerve fibers ending in end plates.

$b$-Granular extrafusal muscle fibers which were innervated by motor nerve fibers ending in terminations of grape.

Key words: Spindles muscle, Iliotibialis muscle, dabb lizard, Uromastix acanthinura

\section{INTRODUCTION}

Neuromuscular spindle have been found and described in the majority of vertebrates. Their structure and innervations vary considerably from one species of animals to another. The most recent studies are limited to mammals ( cat and rabbit) in which as it is well known, the spindle consists of 2-12 intrafusal

muscle fibers surrounded by a fibrous capsule (Barker \& Banks, 2004). On lizard 
in which there is only one intrafusal muscle fiber per spindle, little information was found regarding their morphology. So we found that the study of the structure and innervations of spindle muscle in Uromastix acanthinura would be of interest particularly with silver preparation technique, since the spindle muscle can easily be isolated from the surrounding extrafusal muscle fibers.

\section{MATERIALS AND METHODS}

The iliotibialis muscles of Uromastix acanthinura were obtained from six adult dabb lizards ranging from 134.5 to $136.8 \mathrm{gm}$ in weight, which were killed with an overdose of chloroform and immediately after death, the iliotibialis muscles carefully dissected out where the hind limb of each animal was opened along the dorsal surface. The skin above this muscle was cut and folded backwards, the muscles were cut as close as to ilium attachment, and the connective tissue of attachment to the tibia was dissected free and cut from the bone. The muscles were washed in Ringer's solution then stained by Barker and Ip's modification of deCastro's silver method (Barker \&Ip,1963). They were preserved in glycerin for 4-6 weeks. Once the muscles softened, they were systematically teased into small fascicles, the strips of each fascicle was dissected along their length with a pair of fine needles under dissecting stereomicroscope (zeiss stereo zoom). Teased preparation of spindles were mounted in glycerol and covered by cover slip to see spindle innervations.

\section{RESULTS}

With silver preparation technique the neuromuscular spindles appeared as a spindle-shaped structure situated in the external zone of the muscular bundles, with a paralleled position to the muscle fibers. The external capsule, intrafusal muscle fibers and sensory nerve ending were visible. Two types of spindles were found which distinguished on the basis of difference of their diameters at equatorial region. The first is long capsule spindle had an indistinct, closely fitting capsule surrounding the muscle fiber and afferent nerve endings (Figure 1). The second, is short capsule spindle had a broad prominent capsule that extended for only a short distance along the intrafusal muscle fiber ( Figure 2).

\section{Innervations of spindle muscle: Sensory innervations:}

The length of sensory region was differ in each type of spindles. In long capsule which had a long sensory region, the axon entered an indistinct closely fitted capsule and then extended for a long distance on the intrafusal muscle fiber and terminated into several small filaments. In some cases, the axon entered the 


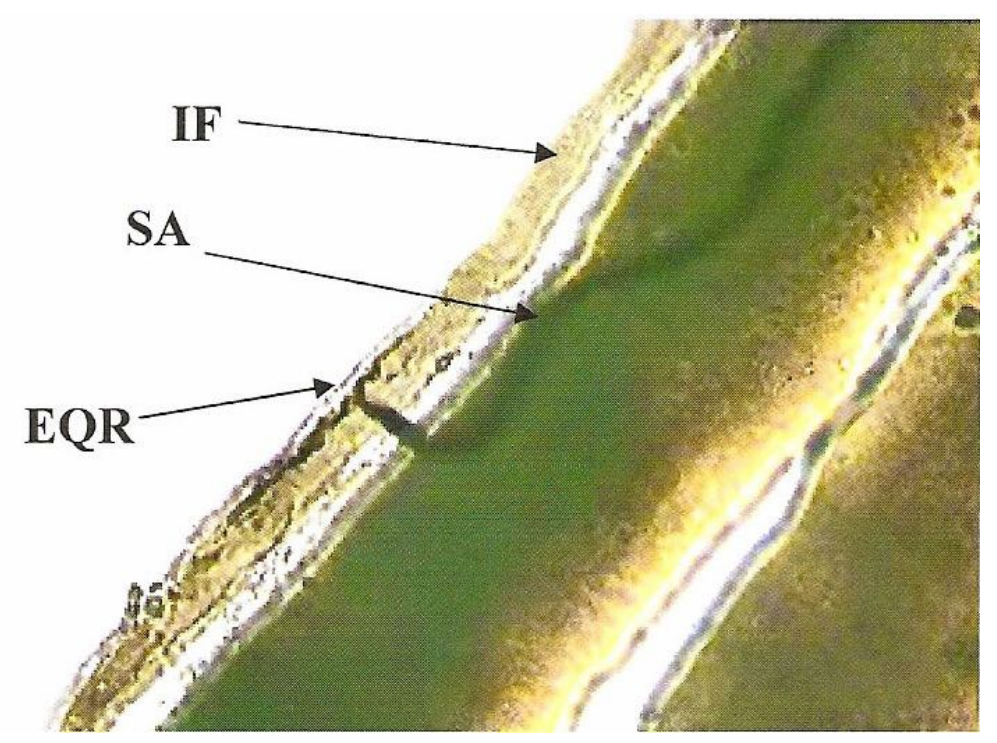

Figure 1: Teased spindle from dabb lizard muscle showing long capsule spindle innervated by a sensory axon that branch after ending on the intrafusal fiber at equatorial region (Silver stain, $x$ 770). where IF= Intrafusal muscle fiber, $\mathrm{SA}=$ Sensory axon, $\mathrm{EQR}=$ Equatorial region.

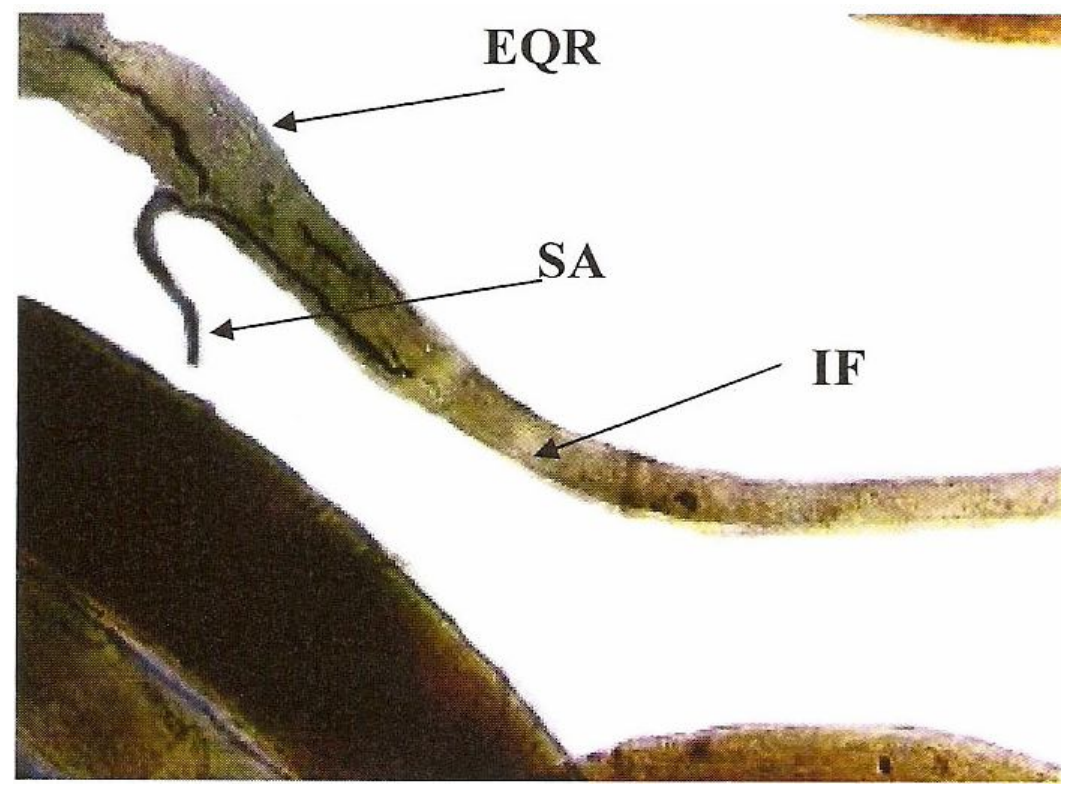

Figure 2: Short capsule spindle innervated by a sensory axon that branch after ending on the intrafusal fiber at equatorial region (Silver stain, $x 190$ ), where EQR=Equatorial region. $S A=$ Sensory axon, $I F=$ Intrafusal muscle fiber. 
capsule and then trifurcated sending two long and one short branch to intrafusal muscle fiber (Figure 3). Few spindles were observed with an axon which was divided at some distance from the spindle and supplied two adjacent sensory regions of two muscle spindles (Figure 4). In short capsule spindle with short sensory region, the axon branched after entering the broad capsule and each branch divided further into several fine filaments making contact with the intrafusal muscle fiber at a short distance. In other cases, the axon did not branch after entering the capsule.

\section{Complex spindles:}

A few complex spindles were teased out from the muscles in the form of paired linkage (Figure 5). The majority of intrafusal muscle fibers were seen innervated by a single afferent axon. In some cases, spindles were supplied with two different axons at different distances of the spindles (Figure 6). In another cases, spindles were supplied with two different axons at the same point (Figure 7 ).

\section{Structure of extrafusal muscle fibers:}

The iliotibialis muscle consisted of both granular and agranular fibers. Based on chemical analysis, it was noticed that the agranular muscle fibers were more than the granular muscle fibers. The nerve terminuses on the extrafusal muscle fibers were of two types: plate terminuses, where the motor terminuses ended on muscle fibers in opposite directions along the surface of the muscle fiber and parallel to its axis and grape endings, where the motor terminuses ended across and not along the muscle fiber (Figures 8 and 9).

\section{DISCUSSION}

In accordance with the results obtained from silver impregnation technique, the spindles of lizard appeared in two forms, but the general structure is similar to that observed in other species. It consists of capsules, one intrafusal muscle fiber and nerve endings. Its position is parallel to the extrafusal muscle fibers. We agree with Szepsenwol, (1960) and Proske, (1969) who described two spindle types. The first one had an elongated sensory ending lying on an intrafusal fiber that showed apparently little structural specialization within sensory region. The second type showed that the sensory axon terminated abruptly on portion of the intrafusal fiber. This region was grossly expanded, showing an accumulation of nuclei and lacking of striation. The axon of some spindles did not branch but approach the capsule at an acute angle before entering it, then trifurcates sending two long and one short branches to the intrafusal fiber. In most spindles, the axon branched before entering the capsule then sent only one branch to the intrafusal fiber which was similar to the observations of Proske (1969). Most spindles were found in single units, but a 


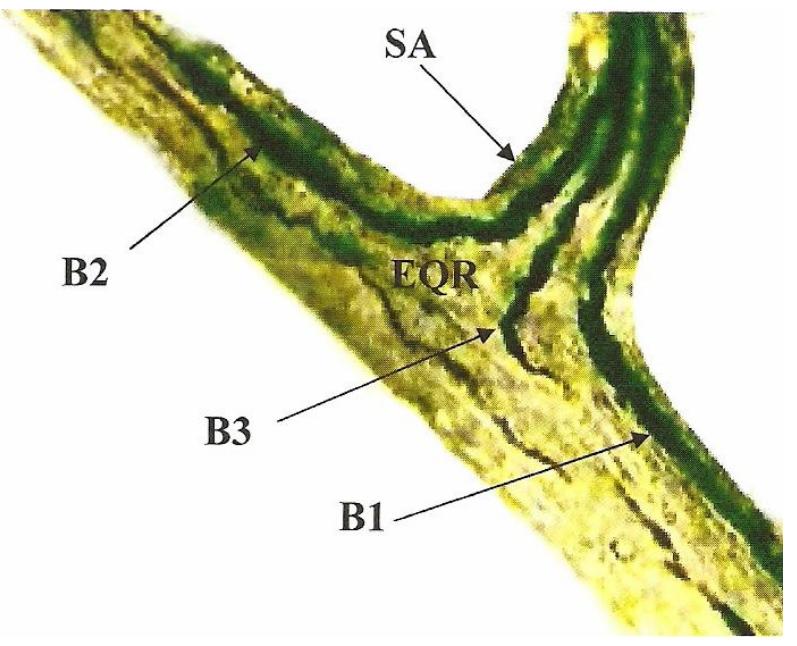

Figure 3: Thick myelinated afferent nerve fiber trifurcates into three after entering the capsule. Two of these branches run parallel to $t$ of the intrafusal muscle fiber in opposite directions and the other stay in equatorial region sending fine filaments, (Silver stain, $x$ 770), where SA= Sensory axon, B1, B2 and B3= branches of sensory axon. EQR= Equatorial region.

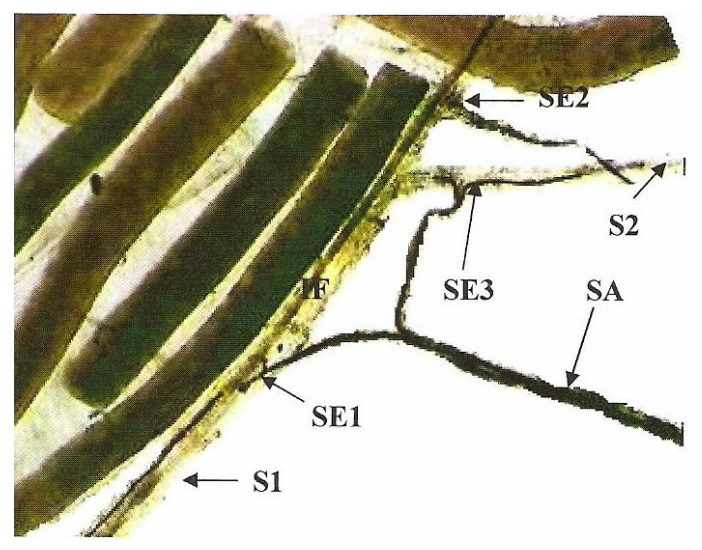

Figure 4 : Short capsule spindle (on left) and long capsule spindle (on right) innervated by branches of the same sensory axon (Silver stain, x190) where SE1 sensory end one, SE2= Sensory end two, SE3= Sensory end three S1= muscle spindle 1, S2 = Muscle spindle 2, SA= Sensory axon. 
A

B
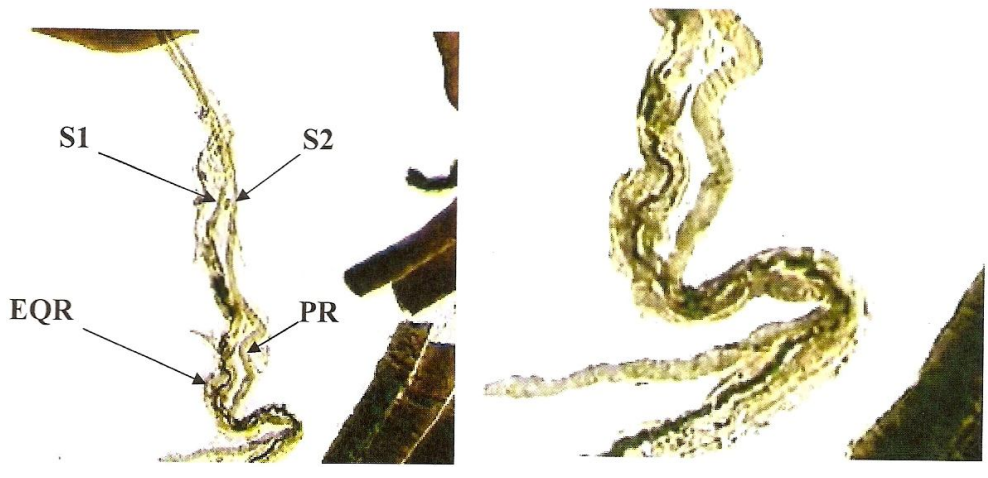

Figure 5: Complex spindle linked as pair, one at equatorial region and other at polar region (Silver stain, x70) in Plate A, where $\mathrm{S} 1$ = Muscle spindle 1, S2 muscle spindle 2, EQR= Equatorial region. PR= Polar region. Plate B. A detail at high magnification (Silver stain, x190)

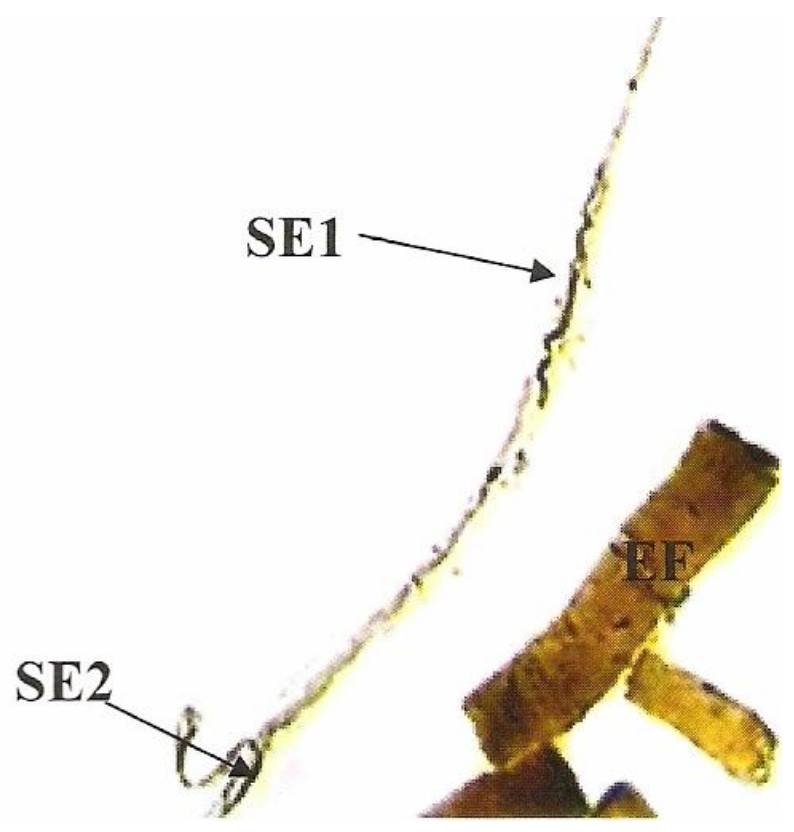

Figure 6: Long capsule spindle innervated by two separate sensory axons (silver stain, x70), where SEl= Sensory end one., SE2= Sensory end two , EF= Extrafusal muscle fiber. 


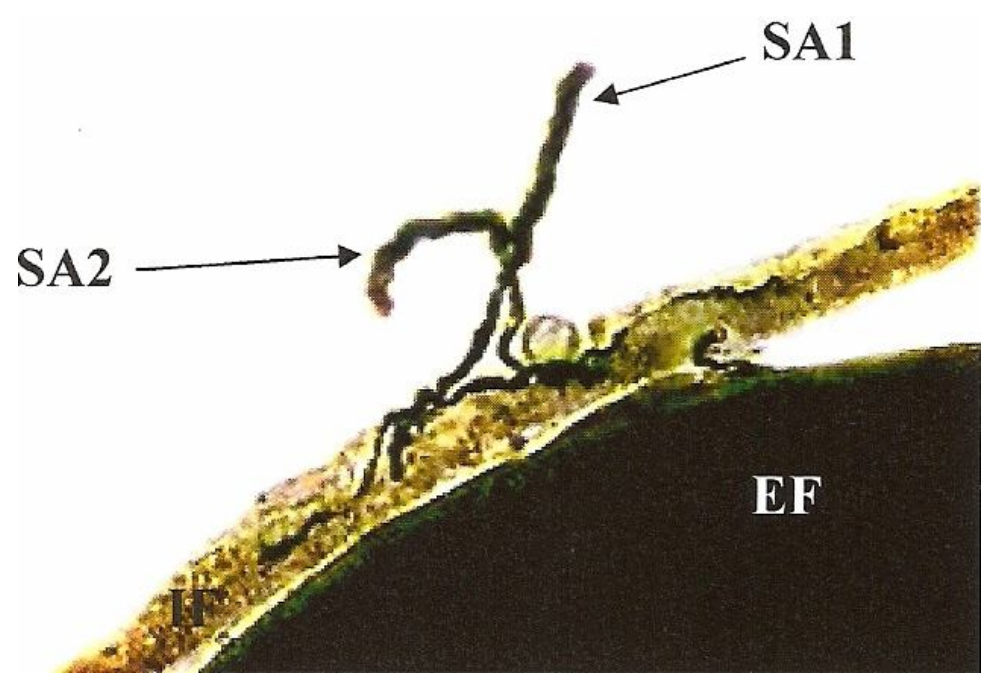

Figure 7: Photomicrograph of a teased spindle from dabb lizard muscle showing long capsule spindle innervated with two different axons at the same point (Silver stain, $x 375$, where SA1 sensory axon one, SA2= Sensory axon two, IF=Intrafusal muscle fiber , EF= Extrafusal muscle fiber.

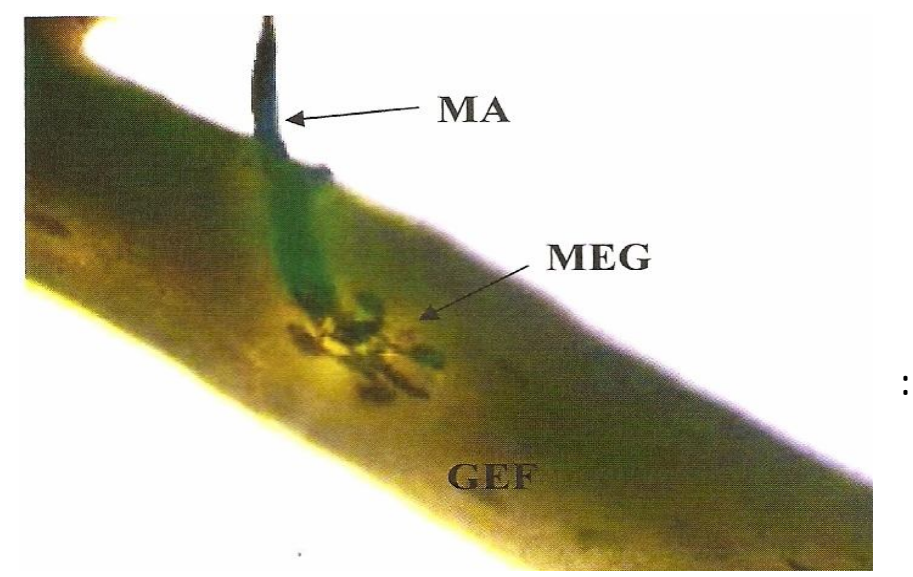

Figure 8: Granular extrafusal muscle fiber innervated by motor fiber in grape termination (Silver stain, $\mathrm{x} 770$ ). where $\mathrm{GEF}=$ Granular extrafusal fiber, $\mathrm{MEG}=$ Motor end grape $\quad \mathrm{MA}=$ Motor axon 


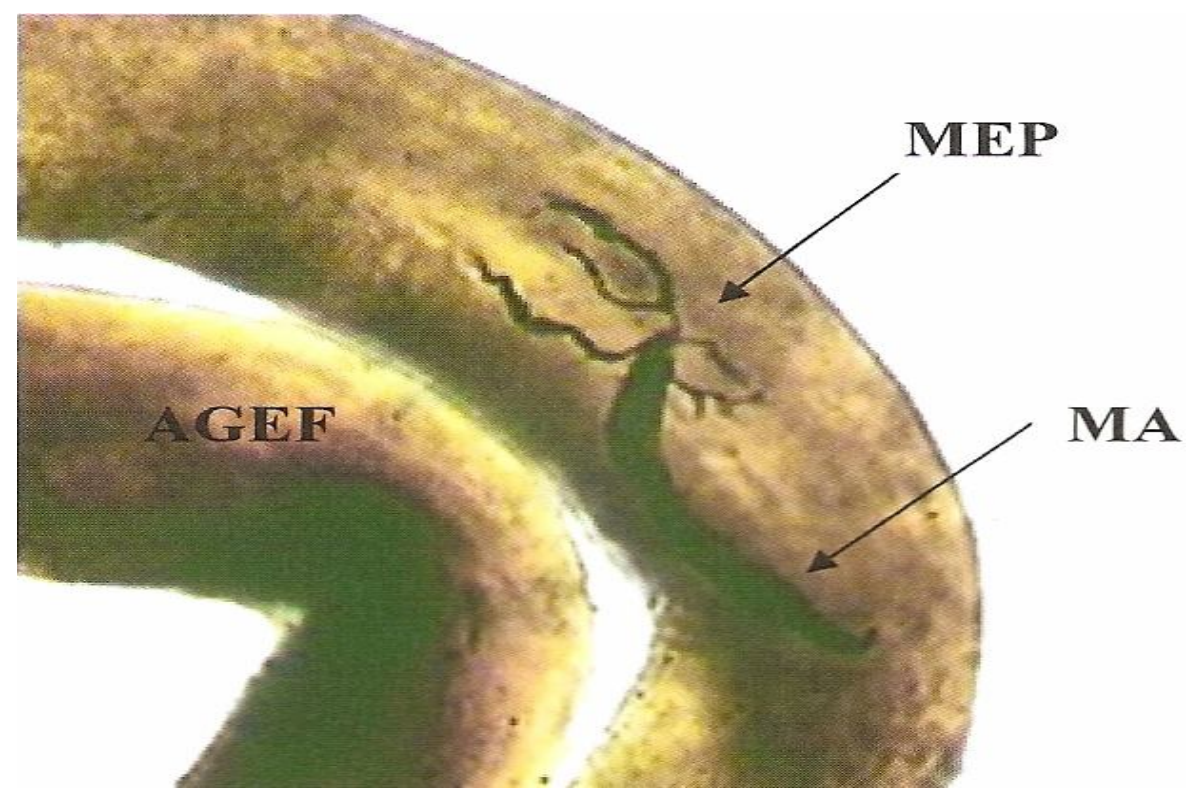

Figure 9: Agranular extrafusal muscle fiber innervated by motor fiber in plate termination (Silver stain, $x$ 770), where MEP= Motor end plate, AGEF= Agranular extrafusal muscle fiber., MA= Motor axon.

few spindles were found in conjunctive arrangements. The rare incidence of complex configuration was previously reported in hind limb muscles of rat by Hartung and Asmussen (1988). These arrangements were of two types: Tandem associations in which two axons supply adjacent sensory regions on the same intrafusal muscle fiber. This agree with proske (1969) observations on the tibialis anterior muscle of lizard Tiliqua nigrolutea. The second type was paired association in which the spindles lay side by side, one at the equatorial region and the other on the polar region. This agree with Bakker and Richmond (1981\&1982) observations on intervertebral muscles of cat. Extrafusal motor innervations was of two types, the plates and the grape. The grape endings were composed of bunches of grape-like terminations, this observation agrees with Barker (1974) and in some lizard, Ichiki, et al.(1976).

\section{Conclusion}

From these results, it could be concluded that a complex spindles were observed and they were having two forms, paired linkage where spindles lay side by side and tandem spindle which contained two adjacent sensory regions.Also The extrafusal muscle fibers were of two types, A granular extrafusal muscle fibers which were innervated by motor nerve fibers ending in end plates and 
granular extrafusal muscle fibers which were innervated by motor nerve fibers ending in terminations of grape.

\section{REFERENCES}

Bakker,D.A., and Richmond,F.J. (1981). Two types of muscle spindles in cat neck muscle: a histochemical study of intrafusal fiber composition. Journal of Neurophysiol., 45: 973-986.

Bakker,D.A., and Richmond,F.J. (1982). Muscle spindle complexes in muscle around upper cervical vertebrae in the cat. Journal of Neurophysiol.,48: 6274.

Barker,D. (1974). The morphology of muscle receptor. In: Muscle Receptors. Handbook of Sensory physiology. (ed. C.C. Hunt) مـ , Springer-Verlag, Berlin, 1(2): 1-190.

Barker,D. and Banks,R.W. (2004). The spindle. In: Myology. (Edition of A.G. Engel and B. Q. Barker) $3^{\text {th }}$ ed, McGraw-Hill, New York, 333-660.

Barker,D. and Ip,M.C. (1963). A silver method for demonstrating the innervations of mammalian muscle in teased preparation. Journal of Physiol., 169: 73-74.

Hartung,V. and Asmussen, G. (1988). Der Einfluss des Lebensalters auf die Anzahl, Verteliung and lange der Muskelspindlen und ihrer kapsen in M. Soleus der Ratte. Z. Mikrosk. Anat. Forsch., 102: 655-676.

Ichiki, M., Nakagaki,A.,Kouishi, and Fukami, Y. (1976). The innervations of muscle spindles in the snake, Elpha quadrivirgata. Journal of Anat., 22(1): 141-167.

Proske, U. (1969). The innervation of muscle spindles in the lizard Tiliqua nigrolutea. Journal of Anat., 105: 217-230.

Szepsenwol, J. (1960). The neuromuscular spindle in lizard Anolis cristatellus. Journal of Cell, 61: 21-37. 


\title{
الشكل العام للمغازل العضلية والتعصيب بالعضلة الحرقفية القصبية لسحلية الضب الصغل (Uromastix acanthinura)
}

\author{
آمال الترهونى وسعاد صالح \\ قسم ا لحيوان- كلية العلوم - جامعة قاريونس - بنغازي - ليبيا.
}

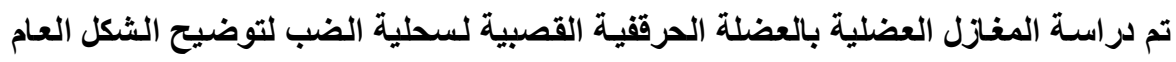

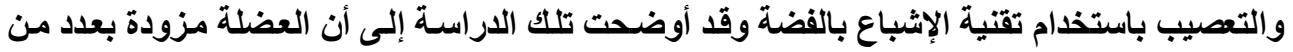

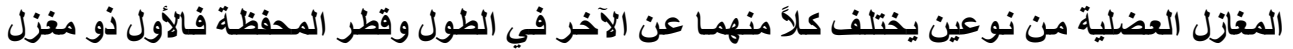

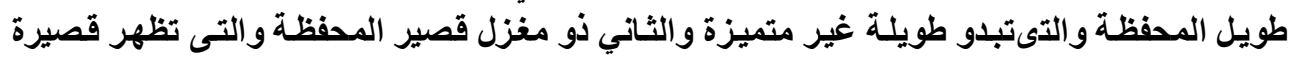

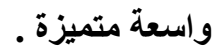

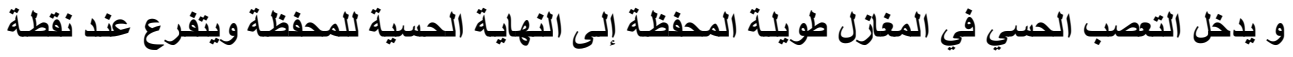

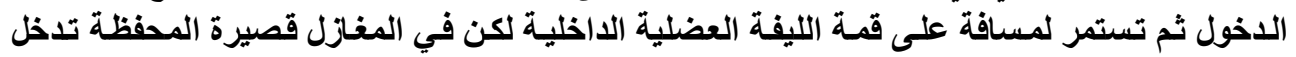
النهاية الحسية المحفظة ثم بعد ذلك تتفرع إلى عدد من الليفات الرفيعة التي تتصل بالليفة العضلية

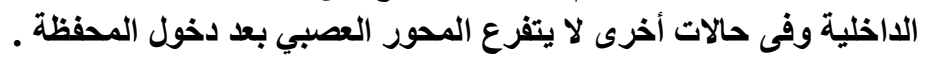

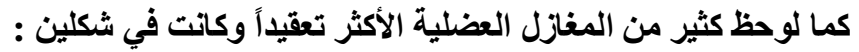
الاول:ترابط مزلوج وفيه امتلت المغازل جنباً إلى جنب.

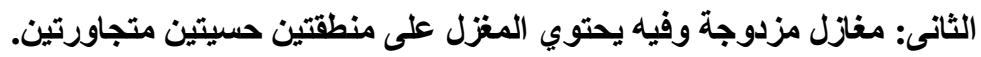
كنلك كاتت الألياف العضلية الخارجية من نو نوعين هما:

- ألياف عضلية خارجية غير محبية والتي عصبت بألياف عصبية حركية منتهية بنهايات حركية صفيحية - ألياف عضلية خارجية محببة والتي عصبت بألياف عصبية حركية منتهية بنهايات حركية عنبية 